\title{
Selectivity, Quality Adjustment and Mean Reversion in the Measurement of House Values*
}

\author{
MIN HWANG \\ National University of Singapore, Singapore \\ E-mail: rsthm@nus.edu.sg \\ JOHN M. QUIGLEY \\ University of California, Berkeley, CA, U.S.A. \\ E-mail:quigley@econ.berkeley.edu
}

\begin{abstract}
This paper develops a model of price formation in the housing market which accounts for the non-random selection of those dwellings sold on the market from the stock of existing houses. The model we develop also accounts for changes in the quality of dwellings themselves and tests for mean reversion in individual house prices. The model is applied to a unique body of data representing all dwellings sold in Sweden's largest metropolitan area during the period 1982-1999. The analysis compares house price indices that account for selectivity, quality change and mean reversion with the conventional repeat sales models used to describe the course of metropolitan housing prices. We find that the repeat sales method yields systematically large biased estimates of the value of the housing stock. Our comparison suggests that the more general approach to the estimation of housing prices or housing wealth yields substantially improved estimates of the course of housing prices and housing wealth.
\end{abstract}

Key Words: house price index, selectivity, mean reversion, hybrid model

\section{Introduction}

Owner-occupied housing is a substantial fraction of aggregate wealth in most advanced countries. For example, in the United States in 1982, the aggregate value of owneroccupied housing, \$2.8 trillion, exceeded the value of all financial wealth held by the household sector, ${ }^{1} \$ 2.0$ trillion (Case et al., 2001). It was not until 1993 that household ownership of financial wealth in the United States equaled ownership of housing wealth (about \$6.2 trillion). Even after the massive run-up in share prices in the late 1990s, it is still the case that aggregate house values are more than 40 percent of household financial wealth.

Despite the size and importance of housing wealth, its magnitude is measured much less

*A previous version of this paper was presented at the Third Cambridge-Maastricht Conference on Real Estate Finance and Investment, Maastricht, June 2002. 
precisely than other forms of household wealth. ${ }^{2}$ For many governmental purposes (e.g., the U.S. Census of Population and Housing) and for many analytic purposes as well (e.g., the Panel Study of Income Dynamics), housing values are measured by owners' estimates of valuation.

In the United States, the dominant technique for estimating price trends from housing market transactions has been the "repeat sales" method. This method is easily replicable and is thus widely used in commercial applications, ranging from mortgage contracts to portfolio valuation. However, it may suffer from three major limitations:

First, the method does not account for quality change in the stock of existing housing. The extent of investment in renovations and repairs to the existing stock of housing is large in absolute terms, and it is large relative to the value of newly constructed housing. In 1989, for example, expenditures for residential improvements in the United States were about $\$ 100$ billion, while the value of newly constructed housing was about $\$ 140$ billion. By 1998, expenditures for residential improvements and repair exceeded $\$ 120$ billion. $^{3}$

Second, the method does not recognize that houses which are sold more frequently in any interval may be a non-random sample of the population of owner-occupied dwellings. Empirical evidence (e.g., Englund et al., 1999) suggests that houses on the market are a decidedly non-random sample of owner-occupied dwellings.

Third, the applications of the repeat sales model assume a random walk in housing prices (Case and Shiller, 1987). With this assumption, pairs of sales provide all the information needed to identify the stochastic structure of housing prices. Each of these issues may be quite important in obtaining accurate estimates of housing wealth or in estimating the prices of standardized dwellings in the housing market.

Of course, the importance of these issues depends upon the ultimate intended use of the constructed index. If the index is intended to measure the market value of the dwellings transacted in a given time interval, then neither the selectivity issue nor the quality change issue is relevant. A perfectly suitable index can be derived from the sample moments of the distribution of sold dwellings. If the index is intended to measure the quality-adjusted market value of dwellings sold in a given interval, then the issue of incorporating quality changes is salient, but the selectivity issue is not germane. If the index is intended to be used to make an inference about the value of the housing stock, however, both quality charge and sample selectivity are relevant. In this case, an index based upon transactions during a given interval is used to make an inference about the entire stock, most of which has not been sold during the interval.

For short-term investors and traders, an index which measures only the level and volatility of transacted dwellings may be preferable. In contrast, for the allocation of portfolios among asset classes, housing versus equities, for example, an index of the value of the stock of housing may be more relevant.

This paper considers the importance of all three of these issues: quality adjustment, sample selectivity, and error structures, in making inferences about the course of housing values and housing prices. We develop a novel statistical model that allows, for the first time, for the analysis of both selectivity and quality change in following the course of house prices. We analyze this model in a context that tests for mean reversion in house prices. 
The model is exercised using a unique body of data which contains observations on all arms length housing sales in Sweden during the period 1982-1999. We estimate the model using data from Sweden's largest metropolitan area: the Stockholm metropolitan housing market. Section 2 below presents the basic model and relates it to previous work on price measurement. Section 3 presents our empirical analysis, and compares the importance of selectivity, quality change and mean reversion in house price measurement. Section 4 is a brief conclusion.

\section{Indices of price and valuation}

Methods for estimating market prices for heterogeneous goods or for items traded infrequently have received considerable attention among applied econometricians and finance professionals. Methods to account for the heterogeneity of goods were extended in the early 1970s (Kain and Quigley, 1970; Griliches, 1971) and have been applied quite widely in the analysis of durables, such as automobiles (Otha and Giliches, 1975), housing (Kain and Quigley, 1975), and home appliances (Hausman, 1979). To account for the heterogeneity of commodities, "hedonic" price models are typically estimated by regressing the observed transactions prices or market values, $V_{t}$, (or sometimes, in the case of automobiles, list prices) on a vector, $\mathbf{X}_{t}=\left(x_{1 t}, x_{2 t}, \ldots, x_{n t}\right)$, describing the qualitative and quantitative attributes of the goods. The estimated coefficients, $b$, represent the implicit marginal prices of each attribute.

$$
V_{t}=b_{0}+\sum_{i=1}^{n} b_{i} x_{i t}+\sum_{\tau=1}^{t} p_{\tau} \delta_{\tau}+\xi_{t}
$$

where $\delta_{\tau}$ is an indicator variable with a value of one for all time periods up to $t$, and $p_{\tau}$ is the change in prices during period $\tau$. $\xi_{t}$ is a random error with mean zero. The subscript $j$ indexing observation is suppressed for ease of exposition.

The price index at $t, P_{t}$, is represented by the third term on the right-hand side of (1). It is often assumed that the statistical relationship is semi logarithmic. The underlying logic is that market value $V$ is the product of price $P$ times quantity $X$, i.e.,

$$
V_{t}=X_{t} P_{t}
$$

The logarithm of the transaction price is regressed upon variables measuring the physical characteristics of the commodities $x_{i t}$ and dummy variables representing time $\delta_{t}$. In this formulation, $\exp \left(\sum_{\tau=1}^{t} p_{\tau} \delta_{\tau}\right)$ is the price index at $t$.

Notwithstanding the popularity of the semi log form, it has been shown that few economically meaningful restrictions can be placed on the form of the hedonic relationship expressed in equation (1). ${ }^{4}$ It is also clear that estimates of the hedonic 
price relationship are conditional upon the accurate measurement of all the elements of the vector of commodity characteristics.

Because theory provides little guidance in the formulation of statistical models of hedonic prices and because many durables such as housing are traded infrequently in thin markets, "repeat sales" methods have been developed to abstract from measuring the hedonic characteristics of these goods.

Consider the difference between transaction prices measured at $t$ and $T$. From equation (1), the relationship is

$$
V_{t}-V_{T}=\sum_{i=1}^{n} b_{i}\left(x_{i t}-x_{i T}\right)+\sum_{\tau=T}^{t} p_{\tau} \delta_{\tau}+\left(\xi_{t}-\xi_{T}\right) .
$$

If the form of the hedonic price function is semi logarithmic and if the characteristics of the commodity are unchanged between sales, the model reduces to

$$
V_{t}-V_{T}=\sum_{\tau=T}^{t} p_{\tau} \delta_{\tau}+\left(\xi_{t}-\xi_{T}\right),
$$

where the left-hand side is a logarithmic difference.

The advantage of this formulation is that, for samples of repeat sales of unchanged commodities, it is not necessary to measure the detailed characteristics of the commodities to estimate the price index implied by equation (1). Models based on repeat sales were introduced by Bailey et al. (1963), and have been applied to fine art (Goetzmann, 1993). They have also been applied extensively to the housing market (see Case and Shiller, 1987), and they form the basis for most commercially developed measures of local housing price variation (e.g., indexes marketed by MRAC, Inc.) as well as the regional housing price information produced by U.S. government agencies (i.e., the OFHEO house price series for states and metropolitan areas). ${ }^{5}$

As noted above, there are several disadvantages of the repeat sales method. First, multiple sales of houses may be non-random samples of the underlying population of dwellings. Thus, if the objective is to estimate the value of the stock of housing assets, rather than merely the value of those units which have been sold in any period, this selectivity bias may be important. In particular, the observable characteristics of houses or of time periods may affect the trading propensity of dwellings. Life cycle savings behavior suggests that young households will purchase smaller, less expensive dwellings and will "trade up" several times as circumstances permit. In this case, with a growing population, a sample of sales would include a disproportionate share of these "starter homes."

Some empirical evidence exists on the potential importance of selectivity in house sales. Case et al. (1997) analyzed the housing characteristics and price appreciation patterns for houses in four U.S. counties. The authors compared houses which sold more frequently with those sold less frequently, finding significant differences in types 
of dwellings and patterns of price change. Gatzlaff and Haurin $(1997,1998)$ analyzed house sales in Dade County, Florida. Clapp and Giacotto (1992) analyzed house sales in Connecticut, and Jud and Seaks (1994) analyzed house sales in Greensboro, North Carolina. These studies all provide evidence that house sales are not a random sample of the stock of houses.

Second, with infrequent sales, the sample sizes for analysis in any market run may be quite small. Verification of the unchanged nature of the underlying housing commodity requires measuring its characteristics; it is a curious research strategy that measures these characteristics and then ignores the measurements in subsequent empirical analyses.

Third, Case et al. (1997) point out that housing transactions are often associated with improvement and remodeling expenditures; that is, the housing appreciation rate includes the effects of investments. Contrary to the assumption in repeat sale method that hedonic characteristics of the housing unit do not change between sales, there might be substantial changes in housing quality, and quality changes and sales probability might be positively correlated. Goetzmann and Spiegel (1995) include an intercept term in repeat sale estimation to reflect the non-temporal appreciation term.

As a result of these factors, a variety of "hybrid" models have been proposed, models which combine many of the desirable properties of both hedonic and repeat sales estimators. For one example, consider the joint estimation of the hedonic and repeat sales regressions for a sample containing some dwellings sold once and some sold several times during a period of observation.

$$
\begin{aligned}
& V_{t}=b_{0}+\sum_{i=1}^{n} b_{i} x_{i t}+\sum_{\tau=1}^{t} p_{\tau} \delta_{\tau}+\xi_{t}, \\
& V_{t}-V_{T}=\sum_{i=1}^{n} b_{i}^{*}\left(x_{i t}-x_{i T}\right)+\sum_{\tau=T+1}^{t} p_{\tau}^{*} \delta_{\tau}+\left(\xi_{t}-\xi_{T}\right), \\
& b_{i}=b_{i}^{*} \quad \text { for all } i, \text { and } \\
& p_{\tau}=p_{\tau}^{*} \quad \text { for all } \tau .
\end{aligned}
$$

Joint estimation of equations (5a) and (5b) subject to the constraint (5c) that the coefficients be identical in the two equations is straightforward. (This is a special case of the model proposed by Case and Quigley, 1991.) More general hybrid specifications with more complex specifications of the error structure are also possible. (See Englund et al., 1998, for a survey and application.)

A sensible specification of the error structure in (5a) and (5b) would be general enough to include mean reversion as well as a random walk, i.e.,

$$
\xi_{j t}=\varepsilon_{j t}+\eta_{j t} \quad \text { where } \quad \varepsilon_{j t}=\lambda \varepsilon_{j, t-1}+\mu_{j t}
$$


and

$$
\begin{aligned}
E\left(\eta_{j t}\right) & =0, \\
E\left(\eta_{j t}^{2}\right) & =\sigma_{\eta}^{2}, \\
E\left(\mu_{j t}\right) & =0, \\
E\left(\mu_{j t}^{2}\right) & =\sigma_{\mu}^{2}, \\
E\left(\varepsilon_{j t}\right) & =0, \\
E\left(\eta_{j t} \mu_{j t}\right) & =0, \\
E\left(\varepsilon_{j t}^{2}\right) & =\frac{\sigma_{\mu}^{2}}{1-\lambda^{2}} .
\end{aligned}
$$

The original Bailey et al. (1963) model assumes the $\lambda=0$ while the Case-Shiller (1987) model assumes $\lambda=1$.

$$
\begin{aligned}
& \operatorname{Var}\left(\xi_{j t}\right)=\frac{\sigma_{\mu}^{2}}{1-\lambda^{2}}+\sigma_{\eta}^{2} \\
& \begin{aligned}
& \operatorname{Var}\left(\xi_{j t}-\xi_{j s}\right)=2\left(1-\lambda^{t-s}\right) \frac{\sigma_{\mu}^{2}}{1-\lambda^{2}}+2 \sigma_{\eta}^{2} \\
& E\left[\left(\xi_{j t}-\xi_{j s}\right)\left(\xi_{j \tau}-\xi_{j \varsigma}\right)\right]=\left(\lambda^{|t-\tau|}-\lambda^{|t-\varsigma|}-\lambda^{|s-\tau|}+\lambda^{|s-\varsigma|}\right)\left(\frac{\sigma_{\mu}^{2}}{1-\lambda^{2}}\right) \\
&+(I(t=\tau)-I(t=\varsigma)-I(s=\tau)+I(s=\varsigma)) \sigma_{\eta}^{2},
\end{aligned}
\end{aligned}
$$

where $I(\cdot)$ is an indicator variable.

Estimation of the model expressed in equation (5) through equation (8) can be accomplished by maximizing the loglikelihood of the system of equation systems (5a), (5b) and (5c). Since, given $\sigma_{\eta}^{2}, \sigma_{\mu}^{2}$ and $\lambda$, all the slope parameters can be estimated by GLS, the loglikelihood of the function can be maximized over these parameters as well as the coefficients $b_{i}$ and $p_{t}$.

This methodology can also be extended to address selectivity - the fact that houses of observable characteristics are more likely to trade and the importance of those 
characteristics may vary over time. In any period, we observe that a dwelling $j$ is sold, $F_{t j}^{0}$, if its sale propensity exceeds some threshold, $F_{t}$ :

$$
F_{t j}=\gamma_{0}+\sum_{i=1}^{m} \gamma_{i} z_{i t j}+\varsigma_{t j}
$$

where $\varsigma_{t j}$ is a random error. We observe house values only at the time of sale, $F_{t j}>F_{t}^{0}$. Thus, the expectation of equation (1) for dwelling $j$ is

$$
E\left(V_{t j}\right)=b_{0}+\sum_{i=1}^{n} b_{i} x_{i t j}+\sum_{\tau=1}^{t} p_{\tau} \delta_{\tau}+E\left(\varepsilon_{t j} \mid F_{t j}>F_{t}^{0}\right)
$$

Similarly, from equation (3)

$E\left(V_{t j}-V_{T j}\right)=\sum_{i=1}^{n} b\left(x_{i t j}-x_{i T j}\right)+\sum_{\tau=T+1}^{t} p_{\tau} \delta_{\tau}+E\left(\left[\varepsilon_{t j} \mid F_{t j}>F_{t}^{0}\right]-\left[\varepsilon_{T j} \mid F_{T j}>F_{T}^{0}\right]\right)$.

Thus, the coefficients estimated from equation (10) or (11), or from some hybrid of them, will be biased if the conditional expectation of the error term is nonzero. However, it is well known (Heckman, 1979) that consistent estimates of the coefficients of equation (10) or (11) may be obtained by modeling the process that selects dwellings into the set of observations on those sold in any period.

Let $I_{t j}$ be an indicator variable with a value of 1 if dwelling $j$ is sold at time $t$ and zero otherwise, and let

$$
\operatorname{prob}\left(I_{t j}=1\right)=\Phi\left(\gamma_{0}+\sum_{i=1}^{m} \gamma_{i} Z_{i t j}\right)
$$

where $\Phi$ is the standard normal distribution, $Z_{i t j}$ are the relevant characteristics, $i=1,2$, $\ldots, m$ of house $j$ at time period $t$, and $\gamma$ is a set of parameters. The inclusion of the inverse Mills ratio $\lambda_{t j}$, derived from this selection process, ${ }^{6}$ in the valuation regression yields unbiased estimates of the parameters, despite non-random sample selection. For example, 
from (10) and (11) the selectivity-corrected valuation models associated with equations $(5 a),(5 b)$ and $(5 c)$ are:

$$
\begin{aligned}
V_{t j} & =b_{0}+\sum_{i=1}^{n} b_{i} x_{i t j}+\sum_{\tau=1}^{t} p_{\tau} \delta_{\tau}+\chi \lambda_{t j}+\xi_{i j} \\
V_{t j} & -V_{T j}=\sum_{i=1}^{n} b^{*}\left(x_{i t j}-x_{i T j}\right)+\sum_{\tau=T+1}^{t} p_{\tau}^{*} \delta_{\tau}+\chi^{*}\left(\lambda_{t j}-\lambda_{T j}\right)+\left(\xi_{t j}-\xi_{T j}\right) \\
b_{i} & =b_{i}^{*} \text { for all } i \\
p_{\tau} & =p_{\tau}^{*} \text { for all } \tau, \text { and } \\
\chi & =\chi^{*}
\end{aligned}
$$

where $\lambda_{t j}$ is the inverse Mills' ratio associated with the probability of observing the sale of house $j$ at time $t$, and $\chi$ is a parameter. Thus, unbiased estimates of the house price index may be obtained from the non-random sample of firms whose valuations are actually observed during any time interval.

\section{Empirical analysis}

In this section, we compare the results from the models described in Section 2 using comprehensive data from a single housing market over an extended period of time. We use micro data on house sales in the Stockholm metropolitan area during the period 19811999 to investigate the importance of quality change in the housing stock as well as the effects of sample selectivity in house sales upon indices of housing prices over time.

The general character of the data we analyze is described in detail elsewhere (Englund et al., 1998). Specifically, the data consist of every arms length sale of owner-occupied housing in the Stockholm metropolitan region from January 1, 1981 through December 31, 1999. Contract data reporting the transaction price for each sale have been merged with tax assessment records containing detailed information about the characteristics of each house. Repeat sales are identified, as is the location of each unit down to the smallest geographical unit, the parish (something akin to a census tract). The data set is exceptional in its detailed description of each dwelling at the date of sale and its identification of repeat sales. Together, these characteristics of the data make possible the comparison between the hybrid and repeat sales method discussed above. Moreover, they permit a comparison of results using different sub-samples.

Earlier and less complete versions of these data (with sales recorded through August 31, 1993) have been used in several other research papers (Englund et al., 1998, 1999). In particular, Englund et al. (1999) provides some evidence on sample selectivity.

During a short time interval, the dwellings that sell more than once are likely to be a non-random sample of the population of dwellings. As the time interval for the analysis increases, differences in the average characteristics of dwellings between properties sold 
once and properties sold more frequently declines. But it is still likely that properties sold many times differ systemically from those sold less frequently.

Table 1 reports the distribution of house sales for owner-occupied dwellings sold in Stockholm during the 19 -year period. A total of 87,155 houses were sold, and a total of 123,668 sales are recorded. More than two thirds of the houses sold were transacted a single time, and 80 percent of the sales were for properties with only one or two transactions. But there is a long tail to the distribution of sales; a few houses were sold many times.

Table 2 reports the average characteristics of dwellings sold various numbers of times during the period. It seems clear that the characteristics of dwellings sold many times differ substantially from those only a few times, but the relationship between price or quality and the number of sales is not monotonic.

Table 3 reports the results of the probit model of the probability of sales of a dwelling in any half-year interval. The model was estimated by constructing event histories for each of the 87,155 dwellings indicating the probability of sale in each of the 76 intervals. The probit model is estimated on these 6,623,780 event histories. As reported in Table 3, the probability of sale in any period differs for properties with different physical characteristics. As the results indicate, smaller dwellings, with less living area on smaller lots are more likely to sell than are larger houses. There are also pronounced differences in the sale probabilities of dwellings with various amenities. In general, trades are more frequent for lower quality dwellings. There is also evidence, not reported in the table, that the probability of sale varies over time for identical dwellings.

Table 4 presents alternative estimates of the price index for the Stockholm housing market over time. Column 1 presents the weighted repeated sales price index based upon all multiple sales of dwellings during the 19-year interval. This model implicitly assumes that there is no quality change in the housing market over time, and it makes no adjustment for variations in the price of housing of different qualities. As such, the model is identical in its definition to the house price indices published for U.S. states and metropolitan areas by the U.S. Office of Federal Housing Enterprise Oversight. As indicated in Table 5, the coefficients of the dummy variables are generally significant and reveal a rising nominal price index during the 19-year period.

Table 1. Number of dwellings and sales of Stockholm houses 1981-1999.

\begin{tabular}{lrc}
\hline Total House Sales & Number of Houses & Number of Sales \\
\hline 1 & 59,550 & 59,550 \\
2 & 20,202 & 40,404 \\
3 & 5,839 & 17,157 \\
4 & 1,296 & 5,184 \\
5 & 239 & 1,195 \\
6 & 26 & 156 \\
7 & 2 & 14 \\
8 & 1 & 8 \\
Total & 87,155 & 123,668 \\
\hline
\end{tabular}


Table 2. Average characteristics of Stockholm dwellings as a function of sales frequency (standard deviations in parentheses).

\begin{tabular}{|c|c|c|c|c|c|c|c|}
\hline Number of Sales & 1 & 2 & 3 & 4 & 5 & 6 & 7 \\
\hline Number of Dwellings & 59,550 & 20,202 & 5,839 & 1,296 & 239 & 26 & 2 \\
\hline Price (000s SEK) & $\begin{array}{c}980.62 \\
(649.8)\end{array}$ & $\begin{array}{c}956.49 \\
(626.4)\end{array}$ & $\begin{array}{c}949.04 \\
(650.8)\end{array}$ & $\begin{array}{c}935.31 \\
(717.4)\end{array}$ & $\begin{array}{c}977.54 \\
(797.2)\end{array}$ & $\begin{array}{l}1006.20 \\
(835.7)\end{array}$ & $\begin{array}{c}1087.81 \\
(790.5)\end{array}$ \\
\hline Living area $\left(\mathrm{m}^{2}\right)$ & $\begin{array}{c}124.24 \\
(40.0)\end{array}$ & $\begin{array}{c}123.46 \\
(38.8)\end{array}$ & $\begin{array}{c}122.12 \\
(40.6)\end{array}$ & $\begin{array}{c}118.68 \\
(43.9)\end{array}$ & $\begin{array}{c}120.46 \\
(50.2)\end{array}$ & $\begin{array}{c}114.00 \\
(38.7)\end{array}$ & $\begin{array}{c}119.50 \\
(30.6)\end{array}$ \\
\hline Utility area $\left(\mathrm{m}^{2}\right)$ & $\begin{array}{c}40.49 \\
(40.8)\end{array}$ & $\begin{array}{c}38.32 \\
(39.7)\end{array}$ & $\begin{array}{c}37.69 \\
(39.5)\end{array}$ & $\begin{array}{c}37.39 \\
(38.9)\end{array}$ & $\begin{array}{c}38.44 \\
(43.8)\end{array}$ & $\begin{array}{c}44.21 \\
(51.7)\end{array}$ & $\begin{array}{c}18.00 \\
(18.7)\end{array}$ \\
\hline Lot size $\left(\mathrm{m}^{2}\right)$ & $\begin{array}{c}1117.24 \\
(2832.6)\end{array}$ & $\begin{array}{r}911.92 \\
(1578.8)\end{array}$ & $\begin{array}{r}802.99 \\
(839.3)\end{array}$ & $\begin{array}{r}838.60 \\
(1155.8)\end{array}$ & $\begin{array}{r}824.01 \\
(942.4)\end{array}$ & $\begin{array}{l}1038.54 \\
(723.7)\end{array}$ & $\begin{array}{c}457.00 \\
(355.9)\end{array}$ \\
\hline Tiled bath (yes = 1) & $\begin{array}{c}0.1699 \\
(0.376)\end{array}$ & $\begin{array}{r}0.1670 \\
(0.373)\end{array}$ & $\begin{array}{c}0.1573 \\
(0.364)\end{array}$ & $\begin{array}{c}0.1588 \\
(0.365)\end{array}$ & $\begin{array}{c}0.1431 \\
(0.350)\end{array}$ & $\begin{array}{r}0.1667 \\
(0.374)\end{array}$ & $\begin{array}{r}0.0000 \\
(0.000)\end{array}$ \\
\hline Sauna $($ yes = 1) & $\begin{array}{c}0.2152 \\
(0.411)\end{array}$ & $\begin{array}{c}0.2244 \\
(0.417)\end{array}$ & $\begin{array}{c}0.2242 \\
(0.417)\end{array}$ & $\begin{array}{c}0.2253 \\
(0.418)\end{array}$ & $\begin{array}{c}0.2243 \\
(0.417)\end{array}$ & $\begin{array}{c}0.2692 \\
(0.445)\end{array}$ & $\begin{array}{r}0.4286 \\
(0.514)\end{array}$ \\
\hline Detached $($ yes $=1)$ & $\begin{array}{c}0.6653 \\
(0.472)\end{array}$ & $\begin{array}{r}0.6137 \\
(0.487)\end{array}$ & $\begin{array}{c}0.5833 \\
(0.493)\end{array}$ & $\begin{array}{c}0.5874 \\
(0.492)\end{array}$ & $\begin{array}{c}0.6033 \\
(0.489)\end{array}$ & $\begin{array}{c}0.6923 \\
(0.463)\end{array}$ & $\begin{array}{c}0.2143 \\
(0.426)\end{array}$ \\
\hline Laundry $($ yes = 1) & $\begin{array}{c}0.7555 \\
(0.430)\end{array}$ & $\begin{array}{c}0.7798 \\
(0.414)\end{array}$ & $\begin{array}{c}0.7799 \\
(0.414)\end{array}$ & $\begin{array}{c}0.7510 \\
(0.432)\end{array}$ & $\begin{array}{c}0.7824 \\
(0.413)\end{array}$ & $\begin{array}{l}0.7115 \\
(0.455)\end{array}$ & $\begin{array}{c}0.9286 \\
(0.267)\end{array}$ \\
\hline Winter quality & 0.8170 & 0.8277 & 0.8254 & 0.8490 & 0.8285 & 0.9615 & 0.5000 \\
\hline Walls (yes $=1$ ) & $(0.387)$ & $(0.378)$ & $(0.380)$ & $(0.358)$ & $(0.377)$ & $(0.193)$ & $(0.519)$ \\
\hline Slate/copper & 0.7637 & 0.7391 & 0.7493 & 0.7486 & 0.7674 & 0.8141 & 0.3571 \\
\hline Roofs $($ yes $=1$ ) & $(0.425)$ & $(0.439)$ & $(0.433)$ & $(0.434)$ & $(0.423)$ & $(0.390)$ & $(0.497)$ \\
\hline
\end{tabular}

Table 3. Probit model of probability of sale in any quarter 1981-1999.

\begin{tabular}{lrr}
\hline & Coefficient & $t$-ratio \\
\hline Living area $\left(\mathrm{m}^{2}\right)$ & -0.01422 & 3.2937 \\
Utility area $\left(\mathrm{m}^{2}\right)$ & -0.00021 & 1.0401 \\
Lot size $\left(\mathrm{m}^{2}\right)$ & -0.03488 & 14.8680 \\
Tiled bath $($ yes $=1)$ & 0.01107 & 3.0693 \\
Sauna $($ yes $=1)$ & 0.02069 & 6.2742 \\
Detached $($ yes $=1)$ & 0.01291 & 2.8933 \\
Laundry $($ yes $=1)$ & -0.00440 & 1.3445 \\
Winter quality walls $($ yes $=1)$ & 0.02049 & 5.9213 \\
Slate/copper roof $($ yes $=1)$ & -0.00034 & 0.1028 \\
Constant & -1.50423 & 59.9201 \\
\hline
\end{tabular}

Notes. The model also contains time dummy variables for each quarter from 1981:I through 1999:IV. The computation is based on $6,623,780$ event histories, computed by observing 87,155 dwellings each for 76 quarterly intervals. Living area, utility area and lot size are all measured in logarithms.

The second column of Table 4 presents the weighted repeat sales model which takes into account the quality changes in the houses sold more than once. Coefficients reported in the table are generally significant, implying that the qualities of houses do change over time and it affects the values of houses. The coefficient on the Mills' ratio is negative and highly 
Table 4. Alternative estimates of price indices for stockholm dwellings: Housing variables ( $t$-statistics in parentheses).

\begin{tabular}{|c|c|c|c|}
\hline & $\begin{array}{l}\text { Repeat Sales With } \\
\text { No Corrections }\end{array}$ & $\begin{array}{l}\text { Repeat Sales } \\
\text { With Selectivity } \\
\text { Correction }\end{array}$ & $\begin{array}{l}\text { Hybrid With } \\
\text { Selectivity } \\
\text { Correction }\end{array}$ \\
\hline Living area $\left(\mathrm{m}^{2}\right)$ & & $\begin{array}{l}0.5435 \\
(43.75)\end{array}$ & $\begin{array}{l}0.7195 \\
(121.7)\end{array}$ \\
\hline Utility area $\left(\mathrm{m}^{2}\right)$ & & $\begin{array}{r}-0.0005 \\
(1.162)\end{array}$ & $\begin{array}{l}0.0074 \\
(38.13)\end{array}$ \\
\hline Lot size $\left(\mathrm{m}^{2}\right)$ & & $\begin{array}{c}0.2606 \\
(23.11)\end{array}$ & $\begin{array}{r}-0.0103 \\
(0.934)\end{array}$ \\
\hline Tiled bath $($ yes = 1) & & $\begin{array}{c}0.0182 \\
(4.003)\end{array}$ & $\begin{array}{c}0.0849 \\
(19.38)\end{array}$ \\
\hline Sauna $($ yes $=1)$ & & $\begin{array}{r}-0.0071 \\
(1.064)\end{array}$ & $\begin{array}{r}0.0506 \\
(7.273)\end{array}$ \\
\hline Detached $($ yes $=1)$ & & $\begin{array}{c}-0.0686 \\
(5.105)\end{array}$ & $\begin{array}{l}0.1815 \\
(31.61)\end{array}$ \\
\hline Laundry (yes = 1) & & $\begin{array}{c}0.0348 \\
(10.21)\end{array}$ & $\begin{array}{l}0.0377 \\
(13.62)\end{array}$ \\
\hline Winter quality walls (yes $=1$ ) & & $\begin{array}{l}-0.0847 \\
(12.92)\end{array}$ & $\begin{array}{r}-0.0675 \\
(9.731)\end{array}$ \\
\hline Slate/copper roof $($ yes $=1)$ & & $\begin{array}{c}0.0276 \\
(4.885)\end{array}$ & $\begin{array}{r}0.0273 \\
(9.369)\end{array}$ \\
\hline Mills' ratio & & $\begin{array}{r}-1.4571 \\
(5.405)\end{array}$ & $\begin{array}{r}0.1021 \\
(0.288)\end{array}$ \\
\hline Constant & & & $\begin{array}{r}2.4380 \\
(3.543)\end{array}$ \\
\hline $\begin{array}{l}\sigma_{\mu} \\
\sigma_{\eta}\end{array}$ & 0.05030 & 0.0473 & $\begin{array}{l}0.0469 \\
0.1480\end{array}$ \\
\hline$\lambda$ & 1 & 1 & 0.993 \\
\hline \multicolumn{4}{|l|}{ Number of observations: } \\
\hline Dwellings & 27,605 & 27,605 & 87,155 \\
\hline Single sales & 0 & 0 & 59,550 \\
\hline Paired sales & 36,633 & 36,633 & 36,633 \\
\hline
\end{tabular}

Note. Each model also contains dummy variables for each quarter from 1981:II through 1999:IV. These coefficients are reported in Table 5.

significant. It shows that the sample of repeat sales, in any interval, is a decidedly nonrandom sample of the housing stock. Exclusive reliance upon the sample of sold dwellings tends to overestimate the value of houses in the entire housing stock. ${ }^{7}$

The third column presents the hybrid model which also accounts for the selectivity of dwellings into the sample of those sold during any period. In addition to correction for selectivity and quality changes, this model permits the errors in individual house prices to follow a mean revering process, rather than a random walk as assumed in the repeat sales model. The estimate of $\lambda$ suggests a slow mean reversion in housing prices; after one year about 92 percent of an exogenous shock to housing prices remains (i.e., $\left.[1-0.993]^{12}\right]$ ). A likelihood ratio test strongly rejects the hypothesis of a random walk in house prices $\left(\chi^{2}=69,453.6\right)$. 
Table 5. Alternative estimates of quarterly price indices for stockholm dwellings ( $t$-statistic in parentheses).

\begin{tabular}{|c|c|c|c|}
\hline & $\begin{array}{l}\text { Repeat Sales Without } \\
\text { Corrections }\end{array}$ & $\begin{array}{l}\text { Repeat Sales With } \\
\text { Selectivity Correction }\end{array}$ & $\begin{array}{l}\text { Hybrid Model With } \\
\text { Selectivity Correction }\end{array}$ \\
\hline \multirow[t]{2}{*}{ 1981: II } & 0.0301 & 0.0317 & 0.0033 \\
\hline & $(2.714)$ & (3.039) & $(0.275)$ \\
\hline \multirow[t]{2}{*}{ 1981: III } & 0.0235 & 0.0180 & 0.0056 \\
\hline & (2.013) & (1.632) & $(0.409)$ \\
\hline \multirow[t]{2}{*}{ 1981: IV } & -0.0159 & -0.0016 & -0.0163 \\
\hline & $(1.248)$ & $(0.130)$ & (1.058) \\
\hline \multirow[t]{2}{*}{ 1982: I } & 0.0489 & 0.0697 & 0.0289 \\
\hline & (4.288) & (6.130) & (1.854) \\
\hline \multirow[t]{2}{*}{ 1982: II } & -0.0245 & -0.0368 & 0.0079 \\
\hline & $(2.388)$ & $(3.746)$ & $(0.581)$ \\
\hline \multirow[t]{2}{*}{ 1982: III } & 0.0325 & 0.0229 & 0.0143 \\
\hline & (3.238) & $(2.401)$ & (1.111) \\
\hline \multirow[t]{2}{*}{ 1982: IV } & -0.0285 & -0.0136 & -0.0257 \\
\hline & $(2.570)$ & (1.281) & (1.733) \\
\hline \multirow[t]{2}{*}{ 1983: I } & 0.0436 & 0.0508 & 0.0356 \\
\hline & (3.937) & (4.842) & $(2.457)$ \\
\hline \multirow[t]{2}{*}{ 1983: II } & -0.0110 & -0.0120 & -0.0110 \\
\hline & (1.069) & (1.239) & $(0.847)$ \\
\hline \multirow[t]{2}{*}{ 1983: III } & 0.0148 & 0.0236 & 0.0256 \\
\hline & (1.663) & (2.805) & (2.174) \\
\hline \multirow[t]{2}{*}{ 1983: IV } & -0.0152 & -0.0114 & -0.0232 \\
\hline & (1.558) & (1.233) & (1.776) \\
\hline \multirow[t]{2}{*}{ 1984: I } & 0.0157 & 0.0219 & 0.0239 \\
\hline & (1.594) & $(2.318)$ & $(1.775)$ \\
\hline \multirow[t]{2}{*}{ 1984: II } & 0.0130 & 0.0119 & 0.0083 \\
\hline & $(1.373)$ & $(1.328)$ & $(0.672)$ \\
\hline \multirow[t]{2}{*}{ 1984: III } & 0.0055 & 0.0025 & 0.0052 \\
\hline & $(0.646)$ & $(0.306)$ & $(0.455)$ \\
\hline \multirow[t]{2}{*}{ 1984: IV } & 0.0167 & 0.0193 & 0.0120 \\
\hline & $(1.722)$ & $(2.105)$ & $(0.917)$ \\
\hline \multirow[t]{2}{*}{ 1985: I } & 0.0034 & 0.0043 & 0.0223 \\
\hline & $(0.368)$ & $(0.496)$ & $(1.719)$ \\
\hline \multirow[t]{2}{*}{ 1985: II } & 0.0219 & 0.0244 & 0.0067 \\
\hline & $(2.517)$ & $(2.972)$ & $(0.562)$ \\
\hline \multirow[t]{2}{*}{ 1985: III } & 0.0054 & 0.0037 & -0.0078 \\
\hline & $(0.654)$ & $(0.481)$ & $(0.685)$ \\
\hline \multirow[t]{2}{*}{ 1985: IV } & 0.0322 & 0.0355 & 0.0400 \\
\hline & (3.452) & $(4.025)$ & (3.048) \\
\hline \multirow[t]{2}{*}{ 1986: I } & -0.0206 & -0.0121 & -0.0130 \\
\hline & $(2.100)$ & (1.292) & $(0.960)$ \\
\hline 1986: II & 0.0531 & 0.0468 & 0.0429 \\
\hline & $(5.965)$ & $(5.511)$ & $(3.497)$ \\
\hline 1986: III & 0.0522 & 0.0432 & 0.0392 \\
\hline & $(6.407)$ & $(5.575)$ & $(3.509)$ \\
\hline 1986: IV & 0.0139 & 0.0121 & 0.0376 \\
\hline & $(1.500)$ & (1.394) & $(2.914)$ \\
\hline 1987: I & 0.0778 & 0.0740 & 0.0550 \\
\hline & $(8.124)$ & $(8.153)$ & $(4.010)$ \\
\hline 1987: II & 0.0238 & 0.0247 & 0.0516 \\
\hline & $(2.562)$ & $(2.823)$ & $(3.906)$ \\
\hline 1987: III & 0.0604 & 0.0653 & 0.0362 \\
\hline & $(7.220)$ & $(8.285)$ & $(2.905)$ \\
\hline 1987: IV & 0.0577 & 0.0506 & 0.0818 \\
\hline & $(6.088)$ & $(5.659)$ & $(5.900)$ \\
\hline
\end{tabular}


Table 5. (continued)

\begin{tabular}{|c|c|c|c|}
\hline & $\begin{array}{l}\text { Repeat Sales Without } \\
\text { Corrections }\end{array}$ & $\begin{array}{l}\text { Repeat Sales With } \\
\text { Selectivity Correction }\end{array}$ & $\begin{array}{l}\text { Hybrid Model With } \\
\text { Selectivity Correction }\end{array}$ \\
\hline \multirow[t]{2}{*}{ 1988: I } & 0.0473 & 0.0499 & 0.0499 \\
\hline & $(4.802)$ & $(5.385)$ & $(3.585)$ \\
\hline \multirow[t]{2}{*}{ 1988: II } & 0.0589 & 0.0465 & 0.0714 \\
\hline & $(6.624)$ & $(5.473)$ & $(5.503)$ \\
\hline \multirow[t]{2}{*}{ 1988: III } & 0.1345 & 0.1265 & 0.0566 \\
\hline & $(16.90)$ & $(16.36)$ & (4.653) \\
\hline \multirow[t]{2}{*}{ 1988: IV } & -0.0965 & -0.0916 & -0.0056 \\
\hline & (11.91) & $(11.81)$ & $(0.450)$ \\
\hline \multirow[t]{2}{*}{ 1989: I } & 0.1484 & 0.1552 & 0.0808 \\
\hline & $(18.27)$ & $(20.23)$ & $(6.445)$ \\
\hline \multirow[t]{2}{*}{ 1989: II } & -0.0098 & -0.0121 & 0.0461 \\
\hline & $(1.211)$ & (1.576) & (3.779) \\
\hline \multirow[t]{2}{*}{ 1989: III } & 0.0679 & 0.0741 & 0.0097 \\
\hline & (8.580) & (9.788) & $(0.821)$ \\
\hline \multirow[t]{2}{*}{ 1989: IV } & -0.0394 & -0.0536 & -0.0139 \\
\hline & (4.429) & (6.184) & (1.044) \\
\hline \multirow[t]{2}{*}{ 1990: I } & 0.1114 & 0.1056 & 0.0894 \\
\hline & (11.93) & $(11.82)$ & $(6.493)$ \\
\hline \multirow[t]{2}{*}{ 1990: II } & 0.0073 & -0.0019 & 0.0070 \\
\hline & $(0.791)$ & $(0.219)$ & $(0.515)$ \\
\hline \multirow[t]{2}{*}{ 1990: III } & 0.0194 & 0.0147 & 0.0095 \\
\hline & (2.101) & (1.641) & $(0.694)$ \\
\hline \multirow[t]{2}{*}{ 1990: IV } & -0.0399 & -0.0255 & 0.0218 \\
\hline & (4.277) & (2.726) & $(1.602)$ \\
\hline \multirow[t]{2}{*}{ 1991: I } & 0.0557 & 0.0630 & 0.0059 \\
\hline & (6.308) & $(7.462)$ & $(0.487)$ \\
\hline \multirow[t]{2}{*}{ 1991: II } & -0.0016 & -0.0053 & 0.0035 \\
\hline & $(0.194)$ & $(0.660)$ & $(0.311)$ \\
\hline \multirow[t]{2}{*}{ 1991: III } & -0.0128 & -0.0142 & -0.0117 \\
\hline & (1.415) & (1.663) & $(0.998)$ \\
\hline \multirow[t]{2}{*}{ 1991: IV } & -0.0438 & -0.0451 & -0.0420 \\
\hline & $(3.845)$ & (4.199) & $(2.867)$ \\
\hline \multirow[t]{2}{*}{ 1992: I } & -0.0342 & -0.0221 & -0.0607 \\
\hline & $(2.800)$ & (1.906) & (3.912) \\
\hline \multirow[t]{2}{*}{ 1992: II } & -0.0825 & -0.1059 & -0.0386 \\
\hline & (6.682) & (8.833) & $(2.472)$ \\
\hline \multirow[t]{2}{*}{ 1992: III } & -0.0835 & -0.0933 & -0.0632 \\
\hline & (6.443) & (7.420) & (3.773) \\
\hline \multirow[t]{2}{*}{ 1992: IV } & -0.0001 & 0.0059 & -0.0696 \\
\hline & $(0.008)$ & $(0.464)$ & $(3.886)$ \\
\hline 1993: I & -0.0814 & -0.0729 & -0.0331 \\
\hline & (6.180) & $(5.845)$ & (2.011) \\
\hline 1993: II & 0.0218 & 0.0151 & 0.0113 \\
\hline & $(1.702)$ & (1.249) & $(0.785)$ \\
\hline 1993: III & 0.0236 & 0.0229 & -0.0012 \\
\hline & (1.990) & (2.054) & $(0.093)$ \\
\hline 1993: IV & -0.0082 & -0.0125 & 0.0247 \\
\hline & (0.632) & (1.024) & $(1.731)$ \\
\hline 1994: I & 0.0690 & 0.0674 & 0.0436 \\
\hline & $(5.518)$ & $(5.725)$ & $(3.180)$ \\
\hline 1994: II & 0.0245 & 0.0290 & 0.0456 \\
\hline & (2.040) & $(2.567)$ & (3.523) \\
\hline 1994: III & -0.0144 & -0.0225 & -0.0242 \\
\hline & (1.193) & (1.979) & (1.834) \\
\hline
\end{tabular}


Table 5. (continued)

\begin{tabular}{|c|c|c|c|}
\hline & $\begin{array}{l}\text { Repeat Sales Without } \\
\text { Corrections }\end{array}$ & $\begin{array}{l}\text { Repeat Sales With } \\
\text { Selectivity Correction }\end{array}$ & $\begin{array}{l}\text { Hybrid Model With } \\
\text { Selectivity Correction }\end{array}$ \\
\hline \multirow[t]{2}{*}{ 1994: IV } & 0.0083 & 0.0006 & -0.0130 \\
\hline & $(0.635)$ & $(0.049)$ & $(0.883)$ \\
\hline \multirow[t]{2}{*}{ 1995: I } & 0.0154 & 0.0159 & 0.0373 \\
\hline & $(1.265)$ & $(1.379)$ & $(2.606)$ \\
\hline \multirow[t]{2}{*}{ 1995: II } & 0.0157 & 0.0078 & -0.0119 \\
\hline & $(1.295)$ & $(0.684)$ & $(0.875)$ \\
\hline \multirow[t]{2}{*}{ 1995: III } & -0.0398 & -0.0484 & -0.0206 \\
\hline & (3.284) & (4.167) & (1.499) \\
\hline \multirow[t]{2}{*}{ 1995: IV } & 0.0252 & 0.0347 & 0.0180 \\
\hline & (1.841) & (2.677) & (1.194) \\
\hline \multirow[t]{2}{*}{ 1996: I } & -0.0084 & -0.0066 & 0.0039 \\
\hline & $(0.589)$ & $(0.492)$ & $(0.262)$ \\
\hline \multirow[t]{2}{*}{ 1996: II } & 0.0360 & 0.0338 & 0.0344 \\
\hline & $(2.670)$ & $(2.665)$ & $(2.456)$ \\
\hline \multirow[t]{2}{*}{ 1996: III } & 0.0322 & 0.0311 & 0.0043 \\
\hline & $(2.485)$ & $(2.543)$ & $(0.319)$ \\
\hline \multirow[t]{2}{*}{ 1996: IV } & -0.0288 & -0.0279 & 0.0411 \\
\hline & (2.114) & (2.153) & $(2.796)$ \\
\hline \multirow[t]{2}{*}{ 1997: I } & 0.1021 & 0.0865 & 0.0101 \\
\hline & (7.838) & $(7.002)$ & $(0.707)$ \\
\hline \multirow[t]{2}{*}{ 1997: II } & 0.0276 & 0.0256 & 0.0802 \\
\hline & $(2.184)$ & $(2.148)$ & $(5.960)$ \\
\hline \multirow[t]{2}{*}{ 1997: III } & 0.0458 & 0.0516 & 0.0055 \\
\hline & (3.834) & $(4.588)$ & $(0.420)$ \\
\hline \multirow[t]{2}{*}{ 1997: IV } & -0.0209 & -0.0424 & 0.0054 \\
\hline & (1.612) & (3.386) & $(0.348)$ \\
\hline \multirow[t]{2}{*}{ 1998: I } & 0.0862 & 0.0493 & 0.0547 \\
\hline & $(6.724)$ & $(3.522)$ & $(3.122)$ \\
\hline \multirow[t]{2}{*}{ 1998: II } & 0.0468 & 0.0525 & 0.0690 \\
\hline & $(3.723)$ & $(4.410)$ & $(4.867)$ \\
\hline \multirow[t]{2}{*}{ 1998: III } & 0.0502 & 0.0468 & 0.0153 \\
\hline & (3.911) & (3.869) & $(1.136)$ \\
\hline \multirow[t]{2}{*}{ 1998: IV } & -0.0610 & -0.0722 & 0.0141 \\
\hline & (4.129) & $(5.190)$ & $(0.949)$ \\
\hline \multirow[t]{2}{*}{ 1999: I } & 0.1133 & 0.1190 & 0.0199 \\
\hline & $(8.248)$ & $(9.152)$ & (1.333) \\
\hline \multirow[t]{2}{*}{ 1999: II } & 0.1037 & 0.1060 & 0.0964 \\
\hline & (8.304) & $(8.946)$ & $(7.005)$ \\
\hline \multirow[t]{2}{*}{ 1999: III } & -0.0099 & 0.0032 & 0.0222 \\
\hline & $(0.705)$ & $(0.243)$ & $(1.635)$ \\
\hline \multirow[t]{2}{*}{ 1999: IV } & -0.0046 & -0.0027 & -0.0634 \\
\hline & $(0.229)$ & $(0.146)$ & $(3.571)$ \\
\hline
\end{tabular}

One of the advantages of the mean reverting error process is that it allows the efficient estimation of price indices through restrictions on price index slope parameters and on variance parameters. As Table 5 reports, most of the parameters of the price index are highly significant; in only one case is there a discrepancy-statistically significant price index coefficients with different signs. The Mills' ratio is also insignificant, implying that a large portion of the sample selectivity problem can be resolved by including the sample of 


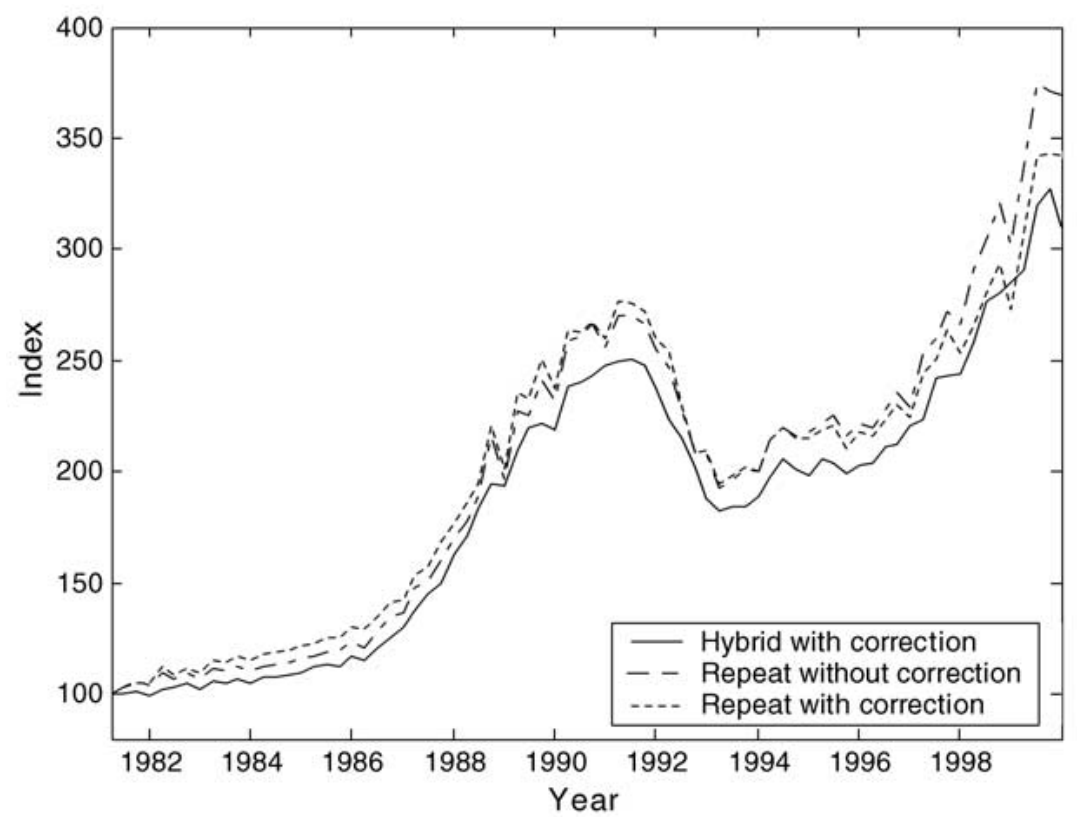

Figure 1. Housing price indices for Stockholm.

houses sold only once in the analysis of house prices. (Note that the hybrid model is estimated using the sample of 87,155 dwellings sold one or more times during the period, not merely the 36,633 paired sales.)

The temporal courses of house prices and the statistical significance of those estimates are indicated in Table 5 and reported graphically in Figure 1. As the figure indicates, when quality change and improvements along with sample selectivity in the housing stock are accounted for, the estimated increase in housing values is substantially smaller than when their trends are ignored. When the random walk assumption is relaxed and more sample points from single-sales houses are included, the estimated increases in housing values are even lower. In fact, the difference between the index from the selectivity-corrected repeat sales model and the index from the hybrid model is often substantial, implying that the random walk assumption imposed on the error process in individual house price substantially overestimates the underlying index of house values.

Figure 2 presents the preferred index of Stockholm housing values derived from the hybrid model which allows for quantity change, controls for sample selectivity, and permits mean reversion in house prices. As indicated in the figure, the price index is very precisely estimated over a long period which itself includes volatile changes in the prices of owner occupied housing. 


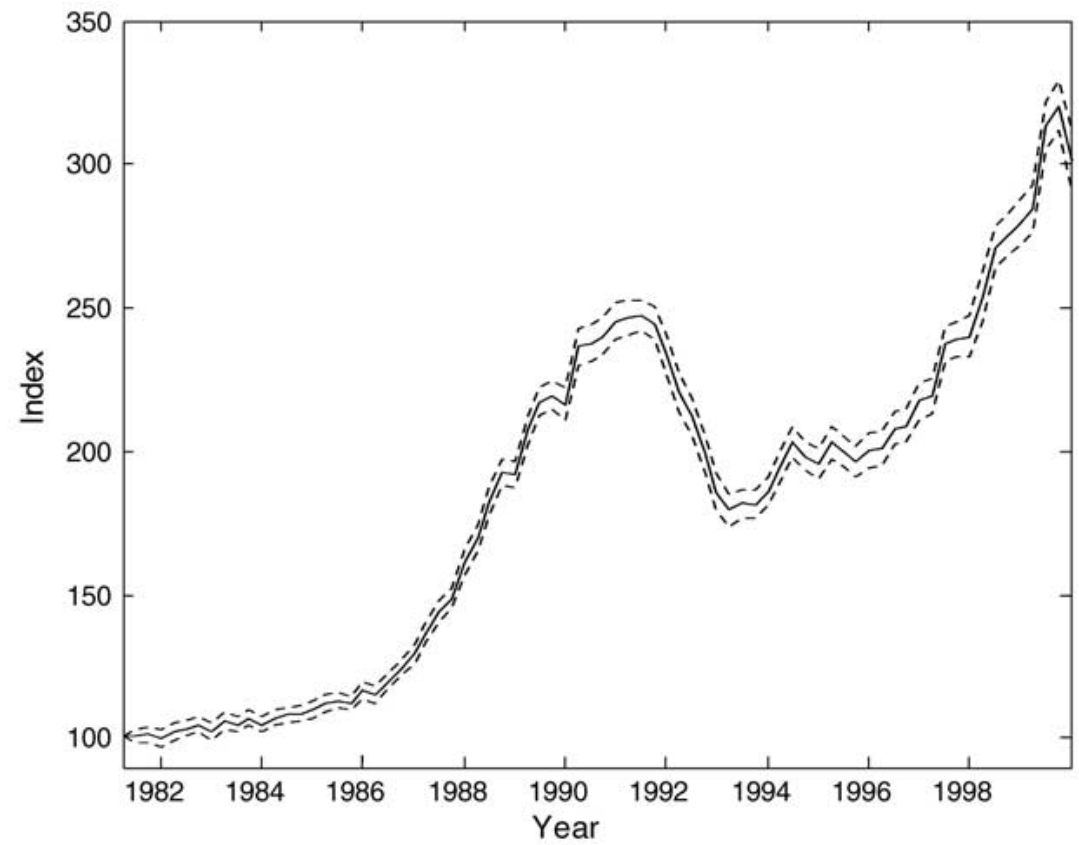

Figure 2. Hybrid house price index for Stockholm with 95 percent confidence interval.

\section{Conclusion}

Routine application of the repeat sales method to estimate house prices has several limitations-potential sample selectivity as well as untested assumptions about constant quality and about the structure of stochastic errors. The effects of those limitations have been addressed separately for particular samples, but not using a comprehensive framework for analysis.

This study uses comprehensive data from the Stockholm housing market during 19811999 to explore the effects of these limitations on estimated housing prices. Using the population of all houses sold more than once, we find that there are substantial changes in housing quality between sales, and that houses sold more than once are not a random sample of the stock of housing. As a result, the repeat sales method, without correcting for quality changes and sample selectivity, yields a systematically biased estimate of the value of the housing stock. By relying upon the hybrid model developed in this paper, we find that sample selection bias can be substantially reduced and that the stochastic nature of individual house prices can be analyzed in a more general way. Our comparison suggests that the more general approach to the estimation of housing prices or housing wealth yields significantly improved estimates of the course of price variations over time. 


\section{Acknowledgments}

We are grateful for the comments of an anonymous referee.

\section{Notes}

1. Financial wealth includes the sum of corporate equities, bonds, pension fund reserves, and mutual funds held by the household sector.

2. Meese and Wallace (1997) suggest that measurement error in real estate prices is a principal reason why financial economists have devoted less attention to real estate despite the large portion of wealth invested in the sector.

3. See U.S. Census Bureau, Current Construction Reports, Series C-30 and C-50.

4. The functional form is derived from the joint envelope of the bid rents of demanders and the isoprofit conditions of suppliers (Rosen, 1974). Under reasonable conditions, the bid and supply functions may imply either a convex or a concave hedonic function.

5. The index is based on observations (beginning in 1975) of the valuations relied upon at origination for at least two conventional conforming mortgages subsequently purchased by either Fannie Mae or Freddie Mac. For a more technical detailed description of the index, see Calhoun (1996).

6. The inverse Mills' ratio is defined as $\lambda_{i j}=\phi\left(\gamma Z_{t j}\right) / \Phi\left(\gamma Z_{t j}\right)$ where $\phi$ is the standard normal density function and $\Phi$ is the cumulative. Note that it may be reasonable to expect that some measures of aggregate economics conditions at $t$ might also help explain variations in the probability of sale of otherwise identical dwellings. On our empirical model, we account for aggregate economic conditions in the most general way by including a dummy variable for each and every time period.

7. Jud and Seaks (1994) found that a hedonic price index was overestimated as a result of sample selection bias. Gatzlaff and Haurin (1997) found that a repeat sales price index was also overestimated for the same reason, but in subsequent work (Gatzlaff and Haurin, 1998) they reported that a hedonic price index was underestimated as a result of sample selectivity.

\section{References}

Bailey, M. H., R. F. Muth, and H. O. Nourse. (1963). "A Regression Method for Real Estate Price Index Construction," Journal of the American Statistical Association 4, 933-942.

Case, B., H. O. Pollakowski, and S. M. Wachter. (1997). "Frequency of Transaction and House Price Modelling," Journal of Real Estate Finance and Economics 14, 173-187.

Case, B., and J. M. Quigley. (1991). "The Dynamics of Real Estate Prices," Review of Economics and Statistics $73(1), 50-58$.

Case, K. E., J. M. Quigley, and R. J. Shiller. (2001). "Stock Market Wealth, Housing Market Wealth, Spending, and Consumption." Paper prepared for the NBER Summer Institute, Cambridge, MA, July 2001.

Case, K. E., and R. J. Shiller. (1987). "Prices of Single-Family Homes Since 1970: New Indexes for Four Cities," New England Economic Review 45-56.

Calhoun, C. A. (1996). OFHEO House Price Indexes: HPI Technical Description, Office of Federal Housing Enterprise Oversight, 1996.

Clapp, J. M., and C. Giacotto. (1992). "Estimating Price Trends for Residential Property: AComparison of Repeat Sales and Assessed Value Methods," Journal of Real Estate Finance and Economics 5, 357-374.

DiPasquale, D., and C. T. Somerville. (1995). "Do House Prices Based on Transactions Represent the Entire Housing Stock? Evidence from the National and Metropolitan HS, 1974-1991," Journal of Housing Economics 4, 100-110. 
Englund, P., J. M. Quigley and C. Redfearn. (1998). "Improved Price Indexes for Real Estate: Measuring the Course of Swedish Housing Prices,', Journal of Urban Economics 44, 171-196.

Englund, P., J. M. Quigley, and C. Redfearn. (1999). “The Choice of Methodology for Computing Housing Price Indices," Journal of Real Estate Finance and Economics 19(2), 91-112.

Gatzlaff, D. H., and D. R. Haurin. (1997). “Sample Selection and Repeat Sales Index Estimates,' Journal of Real Estate Finance and Economics 14(1-2), 33-50.

Gatzlaff, D. H., and D. R. Haurin. (1998). "Sample Selection Biases in Local House Value Indices,' Journal of Urban Economics 43(2), 199-222.

Goetzmann, W. N. (1993). "Accounting for Taste: Art and the Financial Markets over Three Centuries," American Economic Review 83(5), 1370-1377.

Goetzmann, W. N., and M. Spiegel. (1995). "Non-Temporal Components of Residential Real Estate Appreciation,"' The Review of Economics and Statistics 77, 199-206.

Griliches, Z. (1971). Price Indexes and Quality Change. Cambridge, MA: Harvard University Press.

Hausman, J. A. (1979). "Individual Discount Rates and the Purchase and Utilization of Energy Using Durables," Bell Journal of Economics 1(1), 33-54.

Heckman, J. (1979). "Sample Selectivity Bias as a Specification Error,'” Econometrica 47(1), 153-161.

Hwang, M., and J. M. Quigley. (2002). "Price Discovery in Time and Space: The course of Condominium Prices in Singapore,', Berkeley Program on Housing and Urban Policy, Working Paper W02-002.

Jud, D. G., and T. G. Seaks. (1994). “Sample Selection Bias in Estimating Housing Sales Prices,' Journal of Real Estate Research 9(3), 289-298.

Kain, J. F., and J. M. Quigley. (1970). "Measuring the Value of Housing Quality," Journal of the American Statistical Association 65(44), 532-548.

Kain, J. F., and J. M. Quigley. (1975). Housing Markets and Racial Discrimination. New York, NY: Columbia University Press.

Meese, R. A., and N. E. Wallace. (1997). “The Construction of Residential Housing Price Indices: A Comparison of Repeat-Sales, Hedonic-Regression, and Hybrid Approaches,' Journal of Real Estate Finance and Economics 14(1-2), 51-73.

Otha, M., and Z. Giliches. (1975). "Automobile Prices Revisited: Extensions of the Hedonic Price Hypothesis," In N. E. Terleckyj (ed.), Household Production and Consumption. Chicago, IL: University of Chicago Press. Rosen, S. S. (1974). "Hedonic Prices and Implicit Markets,", Journal of Political Economy 82(1), 34-55.

Zellner, A. (1962). "An Efficient Method of Estimating Seemingly Unrelated Regressions and Tests of Aggregation Bias,' Journal of the American Statistical Association 57, 500-509. 